\title{
Nitrogen loading levels affect abundance and composition of soil ammonia oxidizing prokaryotes in semiarid temperate grassland
}

\author{
Xin-Yi Shen • Li-Mei Zhang • Ju-Pei Shen • \\ Ling-Hao Li • Chao-Lei Yuan • Ji-Zheng He
}

Received: 12 March 2011 /Accepted: 28 April 2011 /Published online: 19 May 2011

(C) Springer-Verlag 2011

\begin{abstract}
Purpose Global nitrogen deposition has profound impact on the terrestrial ecosystem including the semiarid temperate grassland, causing vegetation community shifts and soil acidification. Little is known regarding the effect of nitrogen $(\mathrm{N})$ deposition on the belowground microbial communities. This study aimed to examine the response of ammonia-oxidizing bacteria (AOB) and archaea (AOA) to added $\mathrm{N}$ in semiarid temperate grassland.

Materials and methods We studied the changes of AOB and $\mathrm{AOA}$ by using molecular techniques targeting amo $A$ genes along a urea fertilization gradient, i.e., 0,1 , $2,4,8,16,32,64 \mathrm{~g} \mathrm{~N} \mathrm{~m}^{-2}$ year $^{-1}$, in a 6-year field experiment of semiarid temperate grassland, Inner Mongolia of China.

Results and discussion AOB community responded to urea$\mathrm{N}$ substrate clearly, and $\mathrm{N}$ addition rates $2-4 \mathrm{~g} \mathrm{~N} \mathrm{~m}^{-2}$ year $^{-1}$
\end{abstract}

X.-Y. Shen · L.-M. Zhang $(\varangle) \cdot$ J.-P. Shen · C.-L. Yuan •

J.-Z. He $(\bowtie)$

State Key Laboratory of Urban and Regional Ecology,

Research Center for Eco-Environmental Sciences,

Chinese Academy of Sciences,

Beijing 100085, People's Republic of China

e-mail: zhanglm@rcees.ac.cn

J.-Z. He

e-mail: jzhe@rcees.ac.cn

X.-Y. Shen • C.-L. Yuan

Chinese Academy of Sciences, Graduate University,

Beijing 100049, People's Republic of China

L.-H. Li

State Key Laboratory of Vegetation and Environmental Change, Institute of Botany, Chinese Academy of Sciences,

Beijing 100093, People's Republic of China induced an increase in its abundances and the shift of its composition. However, AOA community remained unchanged and the highest $\mathrm{N}$ loading at $64 \mathrm{~g} \mathrm{~N} \mathrm{~m}^{-2}$ year $^{-1}$ even decreased its abundance. Moreover, higher $\mathrm{N}$ loading rates (more than $16 \mathrm{~g} \mathrm{~N} \mathrm{~m}^{-2}$ year $^{-1}$ ) significantly decreased the diversity of $\mathrm{AOB}$ but not AOA, as indicated by the decrease of its Shannon and Evenness indices.

Conclusions The relative long-term nitrogen loading of more than 2-4 g N m${ }^{-2}$ year $^{-1}$ resulted in diversity loss of $\mathrm{AOB}$ in this semiarid temperate grassland. Increasing $\mathrm{N}$ loading altered $\mathrm{AOB}$ abundance and composition, but AOA showed nonsignificant changes.

Keywords Ammonia oxidizing bacteria $\cdot$ Ammonia oxidizing archaea $\cdot a m o A$ gene $\cdot$ Inner Mongolia Nitrification $\cdot$ Nitrogen deposition

\section{Introduction}

Ammonia oxidation, the first and rate-limiting step of nitrification, was thought to be performed almost exclusively by ammonia-oxidizing bacteria (AOB) since the first isolation of the autotrophic prokaryotes in the late nineteenth century. Recent studies demonstrated the potential for significant ammonia oxidation by ammonia-oxidizing archaea (AOA) containing all three ammonia monooxygenase (AMO) subunits (amoA, $a m o B$, and $a m o C$; Könneke et al. 2005; Treusch et al. 2005), whose ecosystem function was previously unknown. The archaeal amoA genes outnumber bacterial amoA genes in the ocean and various soils, suggesting a potential role for archaea, in addition to bacteria, in the global nitrogen cycle (Francis et al. 2005; Nicol and Schleper 2006; Prosser and Nicol 2008; Zhang et al. 
2010). Due to their important function in N cycling, the research of the ecology of $\mathrm{AOB}$ and $\mathrm{AOA}$ has become a subject of intense research over recent years.

Nitrogen accumulation through industrial and agricultural processes has dramatic impacts on the biodiversity and ecosystem function (Tilman et al. 1996, 2006; Bai et al. 2004). A number of studies have shown that the abundance and community structure of $\mathrm{AOA}$ and $\mathrm{AOB}$ shifted in response to different ammonium concentrations and fertilizers. AOB community composition was significantly different after incubated with $0.3 \%(\mathrm{wt} / \mathrm{wt})$ and $1 \%$ (wt/wt) N-containing fertilizer for 11 weeks (Avrahami and Conrad 2003). In our previous work, a pronounced difference in the community composition of AOA in response to the different fertilization practices was observed in acid soils after continuous fertilization for 16 years, and that the chemical nitrogen fertilizer treatment decreased the abundance of $\mathrm{AOA}$ and $\mathrm{AOB}$ (He et al. 2007). While in alkaline soils ( $\mathrm{pH}$ 8.3-8.7), long-term (17 years) fertilization practices had clear influence on the abundance and composition of AOB but not on AOA (Shen et al. 2008). In nitrogen-rich grassland soils, neither AOA abundance nor their activity changed with the applications of an ammonia substrate while the number and activity of $\mathrm{AOB}$ increased in response to ammonia additions in microcosms (Di et al. 2009). All these indicate that nitrogen inputs have great impacts on the community, abundance, and activity of AOB and AOA in soils but the influence is different among different soil systems.

The semiarid temperate steppe of Inner Mongolia in northern China is an integral part of the typical vegetation across the Eurasian continent. The soil here has low fertility and $\mathrm{N}$ has been identified to be one of the major limiting factors for biomass and aboveground net primary productivity (Yu et al. 2009). Such ecosystem is therefore likely to be highly sensitive to $\mathrm{N}$ input. For the aboveground plant communities, Bai et al. (2010) identified the critical threshold of $\mathrm{N}$ loading of below $1.75 \mathrm{~g} \mathrm{~N} \mathrm{~m}^{-2}$ year $^{-1}$ for $\mathrm{N}$-induced species loss to mature Eurasian grasslands and of $10.5 \mathrm{~g} \mathrm{~N} \mathrm{~m}^{-2}$ year $^{-1}$ for the changes in aboveground biomass, species richness, and plant functional group composition to both mature and degraded ecosystems. However, the impact of $\mathrm{N}$ loading on the important functional microbes mediating $\mathrm{N}$ transformations underground, ammonia oxidizers in this area, is unknown. In this study, abundance and community structure $\mathrm{AOB}$ and $\mathrm{AOA}$ along eight urea-N fertilization gradients in a 6-year experimental field in Inner Mongolia were investigated, aiming to examine the response of $\mathrm{AOB}$ and $\mathrm{AOA}$ along $\mathrm{N}$ addition gradient and give hints on the impact of $\mathrm{N}$ addition on the underground microorganisms in this area.

\section{Materials and methods}

\subsection{Experimental site and soil sampling}

The experiment was conducted in a semiarid area located

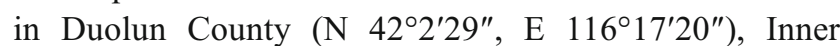
Mongolia Autonomous Region, China. Historically, this area was a pastoral zone, but now it is mainly an agropastoral ecotone. Averaged over the past several decades (1953-2004), the mean annual precipitation was $385.5 \mathrm{~mm}$ with peaks in July and August. Mean monthly air temperatures range from $-17.5^{\circ} \mathrm{C}$ in January to $18.9^{\circ} \mathrm{C}$ in July, with mean annual temperature of $2.1{ }^{\circ} \mathrm{C}$. The soil is a chestnut soil with $62.8 \%$ sand, $20.3 \%$ silt, and $16.95 \%$ clay, bulk density $1.3 \mathrm{~g} \mathrm{~cm}^{-3}$ and $\mathrm{pH}$ 7.1. The vegetation of this site is dominated by Stipa krylovii Roshev, Agropyron cristatum (L.) Gaertn, Cleistogenes squarrosa (Trin.) Keng, Potentilla acaulis (L.), and Artemisia capillaries Thunb (Niu and Wan 2008).

The urea-nitrogen fertilization gradient experiment was established in 2003, including eight treatments and each with four replicate plots in a randomized plot design. Each plot was $10 \times 15 \mathrm{~m}^{2}$, and the distance among them was $1 \mathrm{~m}$. Treatments designated numbers \#1-8 were fertilized along a urea gradient respectively (addition rates of $0,1,2,4,8$, $16,32,64 \mathrm{~g} \mathrm{~N} \mathrm{~m}^{-2}$ year $^{-1}$, respectively) in middle July annually. Treatment \#1 with nil fertilization was denoted as $\mathrm{NF}$, low fertilization treatments \#2-4 were denoted as LF, moderate fertilization treatments \#5-6 were denoted as MF, and high fertilization treatments \#7-8 were denoted as HF. The soil samples were collected in May 2009. Five soil cores $(5 \mathrm{~cm}$ in diameter) were taken from the soil surface $(0$ $10 \mathrm{~cm}$ depth) in each plot and mixed to form one composite sample. Each sample was placed in a sterile plastic bag, kept on ice, and transported to the laboratory. All samples were passed through a $2.0-\mathrm{mm}$ sieve, stored at $4^{\circ} \mathrm{C}$ for analysis of soil characteristics and at $-80^{\circ} \mathrm{C}$ for DNA extraction. Soil $\mathrm{pH}$ was determined with a soil to water ratio of $1: 2.5$, and soil organic matter was determined by the $\mathrm{K}_{2} \mathrm{Cr}_{2} \mathrm{O}_{7}$ oxidationreduction titration method. Nitrate and ammonium were extracted with $2 \mathrm{M} \mathrm{KCl}$ and determined by a continuous flow analyzer (SAN++, Skalar, Holland). Total nitrogen was determined using the Dumas method by an element analyser (Vario EL III, Elementar, Germany).

\subsection{Soil DNA extraction}

Soil DNA was extracted from $500 \mathrm{mg}$ subsample of each sample using the Fast DNA ${ }^{\circledR}$ SPIN Kit for Soil (Q BIOgene Inc., Carlsbad, CA, USA). The extracted DNA was checked on a $1 \%$ agarose gel and the concentration was estimated using a Nanodrop ${ }^{\circledR}$ ND-1000 UV-Vis Spectrophotometer (NanoDrop Technologies). 


\subsection{Quantification of amoA genes by real-time PCR}

Primer pairs amoA1F/amoA2R (Rotthauwe et al. 1997) and Arch-amoAF/Arch-amoAR (Francis et al. 2005) were used for real-time polymerase chain reaction (PCR) quantification of the bacterial and archaeal amoA genes, respectively. The $25-\mu \mathrm{L}$ reaction volume contained $12.5 \mu \mathrm{L}$ SYBR $^{\circledR}$ Premix Ex Taq ${ }^{\mathrm{TM}}$ (TaKaRa Bio Inc.), $0.4 \mathrm{mg} \mathrm{mL}^{-1}$ bovine serum albumin, $400 \mathrm{nM}$ of each AOB primer or $200 \mathrm{nM}$ of each AOA primer, and $2 \mu \mathrm{L}$ of tenfold diluted extracted DNA (1-10 ng) as template. Amplifications were performed on an iCycler iQ 5 thermocycler (Bio-Rad) as follows: $95^{\circ} \mathrm{C}$ for $1 \mathrm{~min}$, followed by 35 cycles of $10 \mathrm{~s}$ at $95^{\circ} \mathrm{C}, 30 \mathrm{~s}$ at $55^{\circ} \mathrm{C}$ for $\mathrm{AOB}$ or $53^{\circ} \mathrm{C}$ for AOA, $1 \mathrm{~min}$ at $72^{\circ} \mathrm{C}$ and plate read at $83^{\circ} \mathrm{C}$ (Zhang et al. 2009).

PCR products amplified from extracted DNA with the primers for real-time PCR assays were gel-purified and ligated into the pGEM-T Easy Vector (Promega, Madison, WI, USA), and the resulting ligation products were transformed into Escherichia coli JM109 competent cells following the manufacturer's instructions. After reamplification with the vector-specific primers T7 and SP6, the positive clones were selected to extract plasmid DNA using a MiniBEST Plasmid Purification Kit (TaKaRa Bio Inc.) and used as amoA gene standards. The plasmid DNA concentration was determined on a Nanodrop ${ }^{\circledR}$ ND-1000 UV-Vis Spectrophotometer (NanoDrop Technologies), and amo $A$ gene copy number was calculated directly from the concentration of the extracted plasmid DNA. Tenfold serial dilutions of a known copy number of the plasmid DNA were subjected to real-time PCR in triplicate to generate an external standard curve. PCR efficiency and correlation coefficients for standard curves were $81.3 \%$ and $r^{2}=0.996$ for $\mathrm{AOB}$, and $101.4 \%$ and $r^{2}=0.996$ for AOA.

\subsection{T-RFLP analysis}

As a rapid screening for the diversity of $\mathrm{AOB}$ and AOA, terminal restriction fragment length polymorphism ( $\mathrm{T}$ RFLP) analysis of amoA gene fragments were performed. The fragments of the amoA genes were amplified with the same primers for the above real-time PCR assays. The 5' terminal of forward primer was labeled with 6carboxyfluorescein. The PCR reaction was the same as described for the above real-time PCR assays excepting that SYBR $^{\circledR}$ Premix Ex Taq ${ }^{\mathrm{TM}}$ was replaced with the Premix Ex Taq $^{\mathrm{TM}}$ (TaKaRa Bio Inc.). The labeled PCR product was purified by Wizard ${ }^{\circledR}$ SV Gel and PCR Clean-Up System (Promega Corporation) and digested at $37^{\circ} \mathrm{C}$ for $3 \mathrm{~h}$ by endonuclease Mbo I (Sau3A I) (TaKaRa Bio Inc.; Ying et al. 2010). After purification, the digestion product of each sample was mixed with deionized formamide and internal standard GeneScan ${ }^{\mathrm{TM}} 1000$ ROX $^{\mathrm{TM}}$ Size Standard (Applied
Biosystems). The mixture was denatured at $95^{\circ} \mathrm{C}$ for $3 \mathrm{~min}$ and placed on ice immediately. The DNA fragments were then size-separated by capillary electrophoresis (3130xl Genetic Analyzer, Applied Biosystems).

The relative abundance of individual terminal restriction fragment (T-RF) was calculated as the percentage of total peak height in a given T-RFLP profile. Only those T-RFs with the relative abundance of $>0.05 \%$ were considered in analyses. The Shannon diversity index $H$ and Evenness index $E$ were used to calculate the T-RF pattern diversity of $\mathrm{AOB}$ and $\mathrm{AOA}$ based on the following equations:

$H=-\sum_{i=1}^{S} p_{i} \ln p_{i}$

$E=H / H_{\max }=H / \ln S$

where, $S$ is the total number of T-RF types in the sample, and $P_{i}$ is the percentage of $i$ th T-RF type.

\subsection{Cloning and sequencing}

Each one clone library of $\mathrm{AOB}$ and AOA amoA gene retrieved from treatment $\# 5$ applied $8 \mathrm{~g} \mathrm{~N} \mathrm{~m}^{-2}$ year $^{-1}$ was created. DNA extracts from four plots of this treatment were mixed and served as the template of PCR. PCR amplification and cloning was performed as described above. The PCR products of bacterial and archaeal amoA genes amplified with the primers for the real-time PCR assays were purified and cloned, as described above. Approximately 130 randomly selected clones from each clone library were sequenced.

Sequences were subject to homology analysis using the software DNAMAN version 4.0 (Lynnon Biosoft). Sequences of chimeric origin were checked by partial treeing analysis and compared with GenBank sequences using BLASTN search. For sequence types that exhibited $>98 \%$ identity to each other, only one representative was used for construction of the phylogenetic tree. The GenBank sequences most similar to the clone sequences in this study and reference sequences for defining clusters were included in the phylogenetic tree construction. Phylogenetic analysis based on nucleotide sequences was performed using MEGA version 4.0 (Tamura et al. 2007) and a neighborjoining tree was constructed using Kimura two-parameter distance with 1,000 replicates to produce bootstrap values.

\subsection{Statistical analyses}

The abundance of amoA gene data was log-transformed to provide variance homogeneity. All statistical analyses were performed using SPSS version 13.0 and one-way analysis 
of variance followed by S-N-K-test was used to check for quantitative differences between treatments. Bivariate correlations were carried out to link different parameters. $P<$ 0.05 was considered to be significant.

\subsection{Nucleotide sequence accession numbers}

The sequences determined in this study were deposited in the GenBank database and assigned accession numbers GU931340 to GU931357 affiliated with AOB and GU931358 to GU931380 affiliated with AOA.

\section{Results}

\subsection{Soil chemical properties}

Soil pH, compared to the NF and LF treatments (\#1-4) ranging from 6.95 to 6.83 , decreased significantly in $\mathrm{MF}$ and HF treatments (\#5-8), with the lowest value of 5.42 0.38 in treatment $\# 8$ (Table 1). Soil $\mathrm{NH}_{4}{ }^{+}-\mathrm{N}$ concentration was relatively low (1.69-2.66 $\mathrm{mg} \mathrm{kg}^{-1}$ soil) in treatments \#1-6, but significantly accumulated (5.14-18.0 $\mathrm{mg} \mathrm{kg}^{-1}$ soil) in the HF treatments (\#7-8). $\mathrm{NO}_{3}{ }^{-}-\mathrm{N}$ concentration in soils (0.61-11.4 mg kg-1 soil) showed a rising trend as $\mathrm{N}$ loading rates increased with a significantly positive correlation with $\mathrm{NH}_{4}{ }^{+} \mathrm{N}$ concentration $(r=0.680, n=32, P<$ 0.01 , two-tailed). Organic matter in these eight treatments varied between 39.5 and $47.1 \mathrm{~g} \mathrm{~kg}^{-1}$ soil and total nitrogen varied between 2.6 and $3.1 \mathrm{~g} \mathrm{~kg}^{-1}$ soil without significant differences.

\subsection{Abundance of $\mathrm{AOB}$ and $\mathrm{AOA}$}

The AOB amoA gene copy numbers did not change too much in treatments \#1-3, but increased 4.9-, 6.9-, 11.7-,
17.6-, and 21.2-fold in treatments \#4-8 compared to the average abundance of treatments \#1-3, respectively (Fig. 1). In contrast, AOA amoA gene copy numbers, ranging from $2.8 \times 10^{8}$ to $7.8 \times 10^{8}$, remained largely unchanged irrespective of the urea- $\mathrm{N}$ addition levels, excepting the treatment $\# 8$ which received the highest $\mathrm{N}$ addition had significantly lower amoA gene copy numbers (see Fig. 1). The AOB amoA gene copy numbers were lower than that of AOA in NF and LF, similar to AOA in MF, but greater than AOA in HF (see Fig. 1). The ratio of AOA to AOB decreased from 21.9 in the lowest $\mathrm{N}$ loading treatment $\# 2$ to 0.2 in the highest $\mathrm{N}$ loading treatment $\# 8$, and negatively correlated with the $\mathrm{N}$ loading rates $(r=$ $-0.737, n=32, P<0.01$, two-tailed).

\subsection{Community structure of AOB and AOA}

The digestion by enzymes Mbo I produced 6-8 T-RFs of AOB and 7-9 T-RFs of AOA amoA gene in the T-RFLP profiles of all samples (Fig. 2). In all treatments, AOB profiles were dominated by 109 and $280 \mathrm{bp} \mathrm{T-RFs} \mathrm{and} \mathrm{the}$ relative abundance of the two T-RFs changed dramatically along the $\mathrm{N}$ gradients. The relative abundance of $109 \mathrm{bp} \mathrm{T}$ RF increased distinctly from $41.4 \%$ to $89.8 \%$, while T-RF 280 bp decreased from $47.1 \%$ to $7.9 \%$ as the $\mathrm{N}$ addition rate increased from $1 \mathrm{~g} \mathrm{~N} \mathrm{~m}^{-2}$ year ${ }^{-1}$ to $64 \mathrm{~g} \mathrm{~N} \mathrm{~m}^{-2}$ year ${ }^{-1}$, indicating clear community shift of $\mathrm{AOB}$ occurred in response to the different $\mathrm{N}$ gradients. T-RFLP profiles of AOA throughout the samples were codominated by 73 , 329,421 , and 443 bp T-RFs with the relative abundance ranging between $10.3 \%$ and $32.5 \%$, and showed no distinct variation among different treatments.

Shannon index $(H)$ and Evenness index $(E)$ are commonly used to characterize species diversity in a community. $H$ and $E$ values of $\mathrm{AOB}$ in $\mathrm{MF}$ and $\mathrm{HF}$ (N addition rates $\geq 16 \mathrm{~g} \mathrm{~N} \mathrm{~m}^{-2}$ year $^{-1}$ ) were significantly lower than

Table 1 Chemical properties of a semiarid temperate grassland soil under different amounts of urea fertilization

\begin{tabular}{|c|c|c|c|c|c|c|c|}
\hline $\mathrm{N}$ loading level & Treatment no. & $\begin{array}{l}\mathrm{N} \text { addition rate } \\
\left(\mathrm{g} \mathrm{N} \mathrm{m}^{-2} \text { year }^{-1}\right)\end{array}$ & $\mathrm{pH}\left(\mathrm{H}_{2} \mathrm{O}\right)$ & Organic matter $\left(\mathrm{g} \mathrm{kg}^{-1}\right)$ & Total $\mathrm{N}\left(\mathrm{g} \mathrm{kg}^{-1}\right)$ & $\mathrm{NH}_{4}^{+}-\mathrm{N}\left(\mathrm{mg} \mathrm{kg}^{-1}\right)$ & $\mathrm{NO}_{3}{ }^{-}-\mathrm{N}\left(\mathrm{mg} \mathrm{kg}^{-1}\right)$ \\
\hline NF & $\# 1$ & 0 & $6.91 \pm 0.16 \mathrm{c}$ & $43.4 \pm 12.1 \mathrm{a}$ & $3.0 \pm 0.2 \mathrm{ab}$ & $1.77 \pm 0.26 \mathrm{a}$ & $0.79 \pm 0.44 \mathrm{a}$ \\
\hline \multirow[t]{3}{*}{ LF } & $\# 2$ & 1 & $6.95 \pm 0.12 \mathrm{c}$ & $44.4 \pm 12.9 \mathrm{a}$ & $2.9 \pm 0.1 \mathrm{ab}$ & $1.69 \pm 0.76 \mathrm{a}$ & $0.61 \pm 0.25 \mathrm{a}$ \\
\hline & $\# 3$ & 2 & $6.91 \pm 0.13 \mathrm{c}$ & $42.3 \pm 10.8 \mathrm{a}$ & $2.8 \pm 0.3 \mathrm{ab}$ & $2.18 \pm 0.74 \mathrm{a}$ & $1.20 \pm 0.78 \mathrm{a}$ \\
\hline & $\# 4$ & 4 & $6.83 \pm 0.15 \mathrm{c}$ & $40.5 \pm 14.4 \mathrm{a}$ & $2.6 \pm 0.2 \mathrm{a}$ & $2.14 \pm 1.00 \mathrm{a}$ & $1.66 \pm 1.53 \mathrm{a}$ \\
\hline \multirow[t]{2}{*}{ MF } & $\# 5$ & 8 & $6.35 \pm 0.27 b$ & $46.5 \pm 15.1 \mathrm{a}$ & $3.1 \pm 0.3 \mathrm{~b}$ & $2.28 \pm 0.62 \mathrm{a}$ & $2.92 \pm 1.66 \mathrm{a}$ \\
\hline & $\# 6$ & 16 & $6.17 \pm 0.19 \mathrm{~b}$ & $47.1 \pm 15.1 \mathrm{a}$ & $3.0 \pm 0.2 \mathrm{ab}$ & $2.66 \pm 0.55 \mathrm{a}$ & $3.99 \pm 1.80 \mathrm{a}$ \\
\hline \multirow[t]{2}{*}{$\mathrm{HF}$} & $\# 7$ & 32 & $5.63 \pm 0.15 \mathrm{a}$ & $39.5 \pm 14.5 \mathrm{a}$ & $2.9 \pm 0.2 \mathrm{ab}$ & $5.14 \pm 2.32 \mathrm{~b}$ & $11.1 \pm 2.63 \mathrm{~b}$ \\
\hline & $\# 8$ & 64 & $5.42 \pm 0.38 \mathrm{a}$ & $41.0 \pm 11.1 \mathrm{a}$ & $2.8 \pm 0.2 \mathrm{ab}$ & $18.0 \pm 2.44 \mathrm{c}$ & $11.4 \pm 3.03 \mathrm{~b}$ \\
\hline
\end{tabular}

Treatments \#1-8 were fertilized with $0,1,2,4,8,16,32$, and $64 \mathrm{~g} \mathrm{~N} \mathrm{~m}^{-2}$ year $^{-1}$, respectively. Four N loading levels were: $N F$ nil fertilizer, $L F$ low fertilizer, $M F$ moderate fertilizer, $H F$ high fertilizer. Mean \pm SD $(n=4)$. Values within the same column followed by the same letter do not differ at $P<0.05$ 
Fig. 1 Abundance of bacterial and archaeal $a m o A$ genes. a Treatments \#1-8 were fertilized with $0,1,2,4,8,16,32$, and $64 \mathrm{~g} \mathrm{~N} \mathrm{~m}^{-2}$ year $^{-1}$, respectively. b Error bars indicate SDs $(n=4)$. Values followed by the same letter $(A O B$ small letter, $A O A$ capital letter) do not differ at $P<0.05$. c Ratio of AOA to AOB amoA gene copies are shown in boxes above the chart

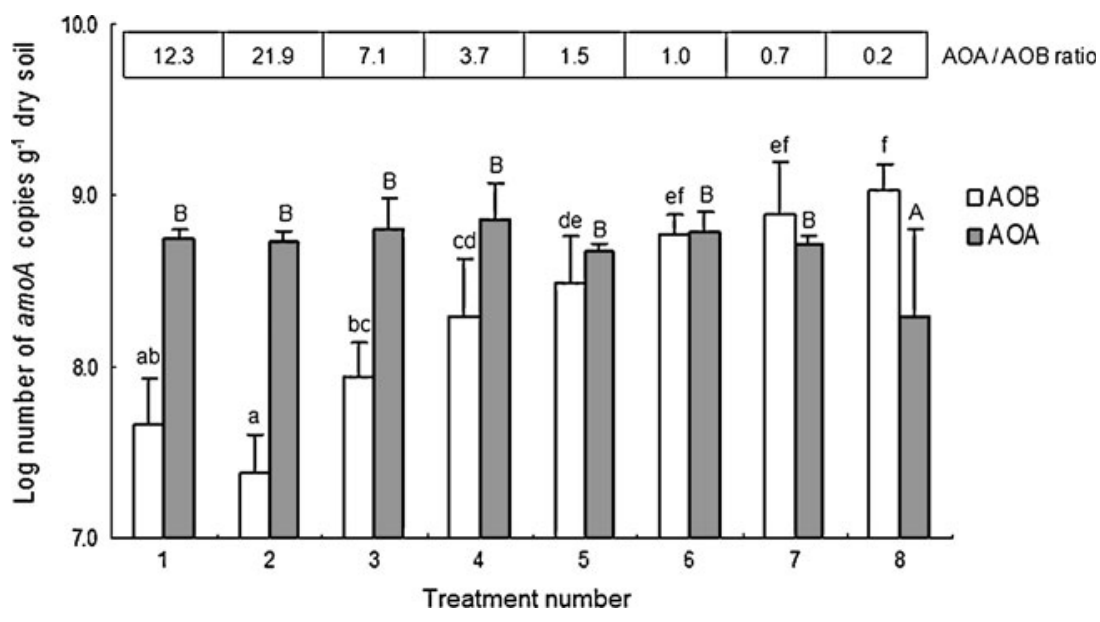

those of NF and LF (Table 2), while the values of AOA showed no significant change among different treatments, indicating high $\mathrm{N}$ addition have significant effect on the diversity of AOB but not on AOA .

To characterize the amoA gene diversity based on the TRFLP, 127 AOB clones and 124 AOA clones of amoA genes retrieved from moderate $\mathrm{N}$ addition treatment $\# 5$ which contained all AOB and AOA T-RF types presented in all treatments were sequenced. Phylogenetic analysis showed that the majority of the AOB sequences were affiliated in the Nitrosospira clusters 3a.1 and 3a.2 with some in Nitrosospira cluster 9 and some in Nitrosomonas
Fig. 2 Relative abundance of T-RFs of bacterial and archaeal amo $A$ gene restricted by Mbo I (Sau3A I). a Treatments $\# 1-8$ were fertilized with $0,1,2,4,8,16,32$, and $64 \mathrm{~g} \mathrm{~N} \mathrm{~m}^{-2}$ year $^{-1}$, respectively. b Error bars indicate SDs $(n=4)$ (a) $\mathrm{AOB}$

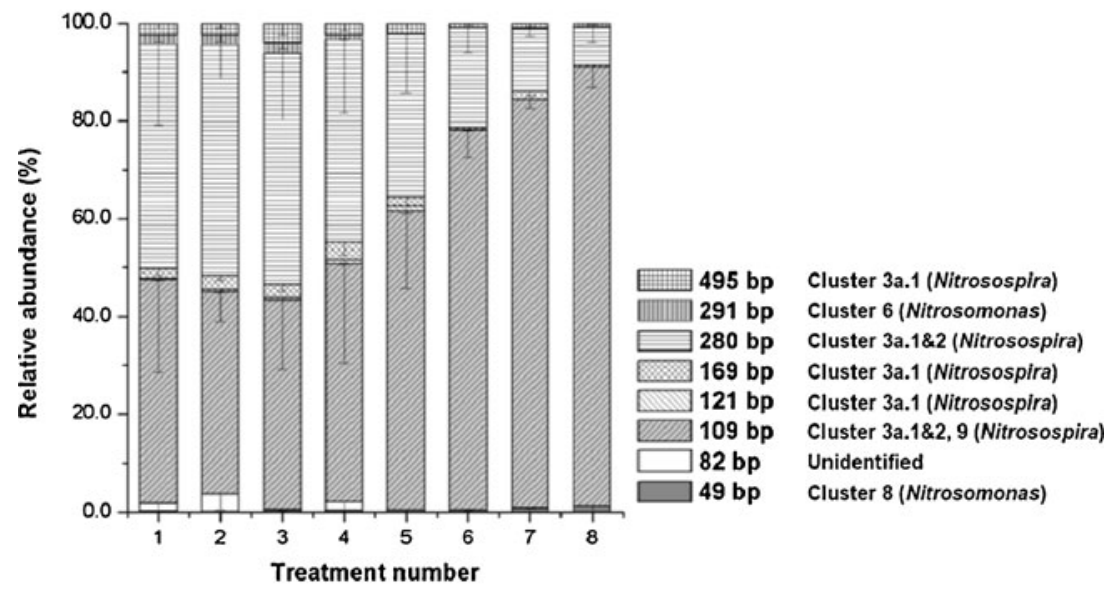

(b) $\mathrm{AOA}$

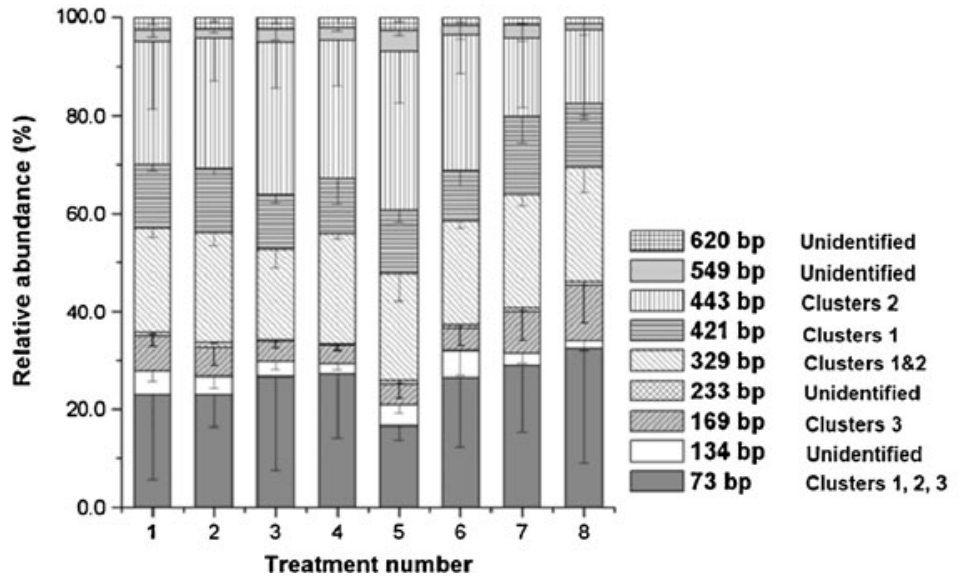


Table 2 Shannon index $(H)$ and Evenness index $(E)$ of AOB and AOA calculated from T-RFLP data

\begin{tabular}{|c|c|c|c|c|c|c|}
\hline \multirow[t]{2}{*}{$\mathrm{N}$ loading level } & \multirow[t]{2}{*}{ Treatment no. } & \multirow[t]{2}{*}{$\mathrm{N}$ addition rate $\left(\mathrm{g} \mathrm{N} \mathrm{m}^{-2}\right.$ year $\left.^{-1}\right)$} & \multicolumn{2}{|l|}{$\mathrm{AOB}$} & \multicolumn{2}{|l|}{$\mathrm{AOA}$} \\
\hline & & & Shannon $(H)$ & Evenness $(E)$ & Shannon $(H)$ & Evenness $(E)$ \\
\hline NF & $\# 1$ & 0 & $0.98 \pm 0.15 \mathrm{~b}$ & $0.47 \pm 0.07 \mathrm{~b}$ & $1.74 \pm 0.17 \mathrm{a}$ & $0.79 \pm 0.08 \mathrm{a}$ \\
\hline \multirow[t]{3}{*}{ LF } & $\# 2$ & 1 & $1.11 \pm 0.01 \mathrm{~b}$ & $0.53 \pm 0.01 \mathrm{~b}$ & $1.76 \pm 0.04 \mathrm{a}$ & $0.80 \pm 0.02 \mathrm{a}$ \\
\hline & $\# 3$ & 2 & $1.02 \pm 0.07 \mathrm{~b}$ & $0.49 \pm 0.03 \mathrm{~b}$ & $1.64 \pm 0.21 \mathrm{a}$ & $0.75 \pm 0.09 \mathrm{a}$ \\
\hline & $\# 4$ & 4 & $1.01 \pm 0.27 \mathrm{~b}$ & $0.48 \pm 0.13 \mathrm{~b}$ & $1.64 \pm 0.14 \mathrm{a}$ & $0.74 \pm 0.06 \mathrm{a}$ \\
\hline \multirow[t]{2}{*}{ MF } & $\# 5$ & 8 & $0.84 \pm 0.18 \mathrm{~b}$ & $0.41 \pm 0.09 \mathrm{~b}$ & $1.76 \pm 0.14 \mathrm{a}$ & $0.80 \pm 0.07 \mathrm{a}$ \\
\hline & $\# 6$ & 16 & $0.61 \pm 0.10 \mathrm{a}$ & $0.29 \pm 0.05 \mathrm{a}$ & $1.66 \pm 0.10 \mathrm{a}$ & $0.75 \pm 0.04 \mathrm{a}$ \\
\hline \multirow[t]{2}{*}{$\mathrm{HF}$} & $\# 7$ & 32 & $0.57 \pm 0.05 \mathrm{a}$ & $0.27 \pm 0.02 \mathrm{a}$ & $1.66 \pm 0.16 \mathrm{a}$ & $0.76 \pm 0.07 \mathrm{a}$ \\
\hline & $\# 8$ & 64 & $0.40 \pm 0.14 \mathrm{a}$ & $0.19 \pm 0.06 \mathrm{a}$ & $1.52 \pm 0.27 \mathrm{a}$ & $0.69 \pm 0.12 \mathrm{a}$ \\
\hline
\end{tabular}

Treatments \#1-8 were fertilized with $0,1,2,4,8,16,32$, and $64 \mathrm{~g} \mathrm{~N} \mathrm{~m}^{-2}$ year $^{-1}$, respectively. Four N loading levels were: $N F$ nil fertilizer, $L F$ low fertilizer, $M F$ moderate fertilizer, $H F$ high fertilizer. Mean \pm SD $(n=4)$. Values within the same column followed by the same letter do not differ at $P<0.05$

clusters 6 and 8 (Avrahami et al. 2002; Avrahami and Conrad 2003; Fig. 3). All AOB sequences could be classified as the same T-RF types as detected in AOB TRFLP analysis by Mbo I (Sau3A I) digestion. Out of 127 AOB sequences, $51 \%$ of sequences corresponded to 109 bp T-RF and $41 \%$ of sequences corresponded to 280 bp T-RF, indicating the two T-RFs dominated AOB community coinciding with the AOB T-RFLP profile. The T-RF 109 bp (in total 65 sequences) was represented by clusters 3a.1, 3a.2, and 9 with varied proportions of $60 \%$, $37 \%$, and $3 \%$, respectively. Similarly, the T-RF 280 bp (in total 52) was represented by clusters 3a.1, 3a.2, but cluster 3a.1 accounted for the absolute majority of this T-RF with a proportion of $98 \%$. All these data imply that AOB community in all treatments is dominated by cluster $3 \mathrm{a} .1$, followed by cluster $3 \mathrm{a} .2$.

All AOA clones identified fell within the soil and sediment lineage and grouped into three distinct clusters, designated as soil and sediment clusters 1,2, and 3 as defined in previous study (Zhang et al. 2009; Fig. 4). The main T-RF types 73, 169, 329, 421, and 443 bp in AOA TRFLP profiles were identified in AOA sequences with the percentage ranging between $4.8 \%$ and $51 \%$. The sequence corresponded to the $73 \mathrm{bp}$ T-RF fell within all three clusters and $329 \mathrm{bp}$ T-RF within clusters 1 and 2 . The other detected phylotypes of 169,421 , and 443 bp only existed in clusters 3,1 , and 2 , respectively.

\section{Discussion}

The abundance of AOB was markedly lower than that of AOA in this low-fertility semiarid temperate grassland soil, which was consistent with studies in other ecosystems (Leininger et al. 2006; He et al. 2007; Nicol et al. 2008;
Shen et al. 2008). However, it was AOB that more sensitively responded to urea-N substrate addition and more than $2 \mathrm{~g} \mathrm{~N} \mathrm{~m}^{-2}$ year $^{-1}$ addition rates had induced significant increase in abundance and community composition shift, whereas the abundance and composition of AOA remained constant except that the highest $\mathrm{N}$ addition rate $\left(64 \mathrm{~g} \mathrm{~N} \mathrm{~m}^{-2}\right.$ year) decreased its abundance. As a result, the relative abundance of AOA and AOB shifted drastically. The ratio of AOA to AOB in this study decreased from a high of 21.9 at low $\mathrm{N}$ loading rate to a low of 0.2 at the highest $\mathrm{N}$ loading rate, well in line with the report for nitrogen-rich grassland soils in New Zealand with ratios varying from 10.7 to 0.2 (Di et al. 2009). The constantly low ammonia concentration corresponding to the increasing nitrate concentration along $\mathrm{N}$ loading gradients indicated that active nitrification mediated by soil ammonia oxidizing prokaryotes was going on, and increasing AOB population induced by $\mathrm{N}$ addition may make an increasing contribution, which is also in agreement with those found that $\mathrm{AOB}$ is mainly driver for nitrification in nitrogen-rich grassland soils in New Zealand (Di et al. 2009). More recent evidences have demonstrated that AOA had high affinity for ammonium and were adapted to low ammonia concentrations (Hatzenpichler et al. 2008; Martens-Habbena et al. 2009; Schleper, 2010). AOA growth was inhibited by the high dose of urine-N substrate in grazed grassland soils in New Zealand was observed recently by Di et al. (2010). All these provide good explanations for our observations that high $\mathrm{N}$ addition did stimulate the growth of $\mathrm{AOB}$ but not $\mathrm{AOA}$, and that $\mathrm{AOB}$ may be responsible for the active nitrification in this soil. Significant decrease in the Shannon and Evenness index values of $\mathrm{AOB}$ in higher nitrogen loading treatments (more than $16 \mathrm{~g} \mathrm{~N} \mathrm{~m}^{-2}$ year $^{-1}$ ) was observed in this study. The results implied the potential risk of diversity loss in microorganisms caused by nitrogen 


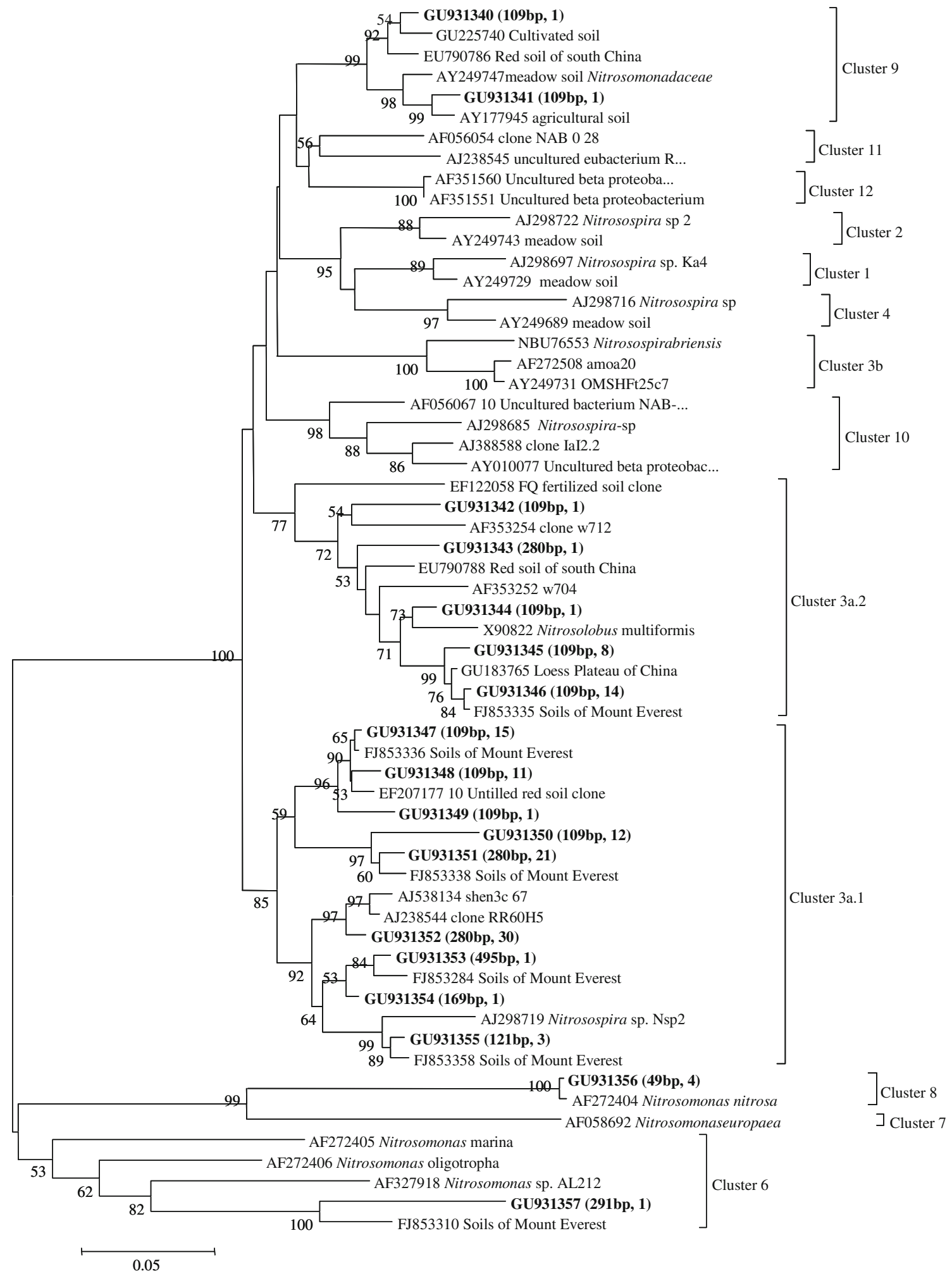

Fig. 3 Neighbor-joining phylogenetic tree of bacterial amo $A$ sequences (465-bp fragment) retrieved from a semiarid temperate grassland soil in Northern China. Designation of the clones in bold includes the information: accession number in the GenBank, following with the TRF length digested by Mbo I (Sau3A I) gained from in silico analysis and the number of clones from treatment \#5 with similarities above $98 \%$ to the listed sequence in the parentheses. Bootstrap values $(>50)$ are indicated at branch points. The scale bar represents $5 \%$ estimated sequence divergence 


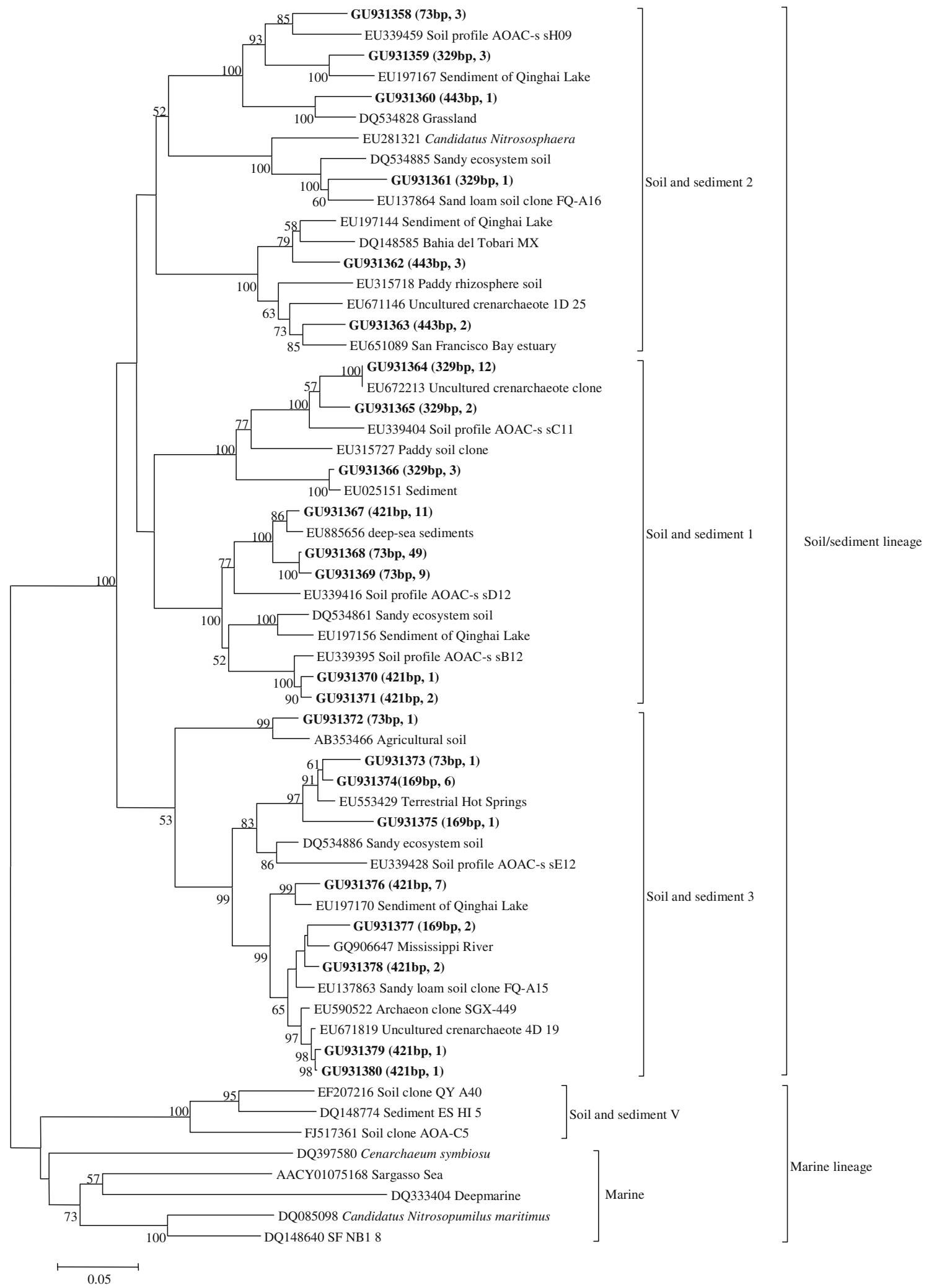

Fig. 4 Neighbor-joining phylogenetic tree of archaeal amo $A$ sequences (594-bp fragment) retrieved from a semiarid temperate grassland soil in Northern China. Designation of the clones in bold includes the information: accession number in the GenBank, following with the TRF length digested by Mbo I (Sau3A I) gained from in silico analysis and the number of clones from treatment $\# 5$ with similarities above $98 \%$ to the listed sequence in the parentheses. Bootstrap values $(>50)$ are indicated at branch points. The scale bar represents 5\% estimated sequence divergence 
addition presented in N-limited grassland ecosystem, coinciding with what has been observed in macroorganisms (Aber et al. 1998; Bai et al. 2010). The $\mathrm{N}$ deposition rate in this area was estimated to be $2 \mathrm{~g} \mathrm{~N} \mathrm{~m}^{-2}$ year $^{-1}$ (Zhang et al. 2008). Closely to the threshold that $\mathrm{N}$-induced AOB community change happened, $2-4 \mathrm{~g} \mathrm{~N} \mathrm{~m}^{-2}$ year $^{-1}$ in this study, while the threshold for plants in this region was found to be approximately $10.5 \mathrm{~g} \mathrm{~N} \mathrm{~m}^{-2}$ year $^{-1}$ (Bai et al. 2010). This also implied that AOB was a potential sensitive indicator for assessing $\mathrm{N}$ addition effect.

Both culture-dependent and independent techniques have suggested the predominance of Nitrosospira over Nitrosomonas in AOB communities in terrestrial ecosystems (Kowalchuk and Stephen 2001; Avrahami and Conrad 2003), whereas Nitrosomonas clusters 7 and 8 were often detected in high $\mathrm{N}$ environments, such as wastewater treatment plants (Geets et al. 2006), manure-treated wetland (Ibekwe et al. 2003), and enrichment cultures (Stephen et al. 1996). Our study revealed that the AOB community was dominated by T-RFs 109 and $280 \mathrm{bp}$ in TRFLP profiles and the two T-RFs were characterized mainly by Nitrosospira Cluster $3 \mathrm{a} .1$ based on cloning and sequencing analysis for treatment \#5. AOB T-RFLP analysis showed that the relative abundance of T-RF $280 \mathrm{bp}$ decreased distinctly but that of T-RF $109 \mathrm{bp}$ increased along the increasing $\mathrm{N}$ loading gradient. Combing the sequencing results that T-RF 280 bp was represented by $98 \%$ of Nitrosospira cluster $3 \mathrm{a} .1$ and $2 \%$ by cluster 3a. 2 and T-RF 109 was represented by $60 \%$ of cluster 3 a. $1,37 \%$ of cluster 3 a. 2 , and $3 \%$ of cluster 9 in treatment $\# 5$, we can deduce that high $\mathrm{N}$ loading decreased the proportion of Nitrosospira cluster 3a.1 and the increase in the relative abundance of T-RF 109 may be caused by the increase in the proportion of cluster 3a.2. All these results demonstrated the AOB community composition and the AOB amo $A$ gene abundance can be consistently altered by the relative long-term $\mathrm{N}$ fertilizer application. All archaeal amoA sequences from this study fell into soil and sediment lineage, suggesting that AOA in this semiarid temperate grassland were distinct from aquatic environments, which was consistent with the results observed in some alkaline soils (Shen et al. 2008; Zhang et al. 2009). Unlike AOB, the AOA community composition was much more stable among the treatments possibly due to their insensitivity to environmental gradients and slow growth (Könneke et al. 2005).

Long-term of 25 years $\mathrm{N}$ fertilizer application could result in soil acidification (McAndrew and Malhi 1992), and in the present study, soil $\mathrm{pH}$ significantly decreased (approximately from 7.0 to 5.5) with the nitrogen loading increase. The reduction in $\mathrm{pH}$ may be another factor inducing the community shift and growth of $\mathrm{AOB}$, but AOA did not show significant change. It was opposite to the changes of $\mathrm{AOB}$ and $\mathrm{AOA}$ communities in soils amended into a gradient of $\mathrm{pH}$ values (approximately 4.97.5) by adding either lime or aluminum sulfate (Nicol et al. 2008). Moreover, it was also inconsistent with the result that soil $\mathrm{pH}$ (approximately 3.7-5.8) played a more important role in AOA populations as found in a Chinese upland red soil under a long-term of 16-year fertilizer application (He et al. 2007), but similar trend was found in an alkaline sandy loam (pH around 8.5; Shen et al. 2008). The reason for this inconsistency might be the active AOA group inhabiting in these soils were different. Another possibility is that the effect of high urea-N substrate addition on $\mathrm{AOB}$ and $\mathrm{AOA}$ predominated over the $\mathrm{pH}$ effect. Addition of $\mathrm{N}$ fertilizer showed no evidence for a community shift of AOB after 4 weeks (Avrahami et al. 2002) or 6 weeks of incubation (Mendum et al. 1999), but a shifts was observed after 16 weeks (Avrahami and Conrad 2003) and 2 years (Horz et al. 2004). Our study provided convincing field experiment evidence for the effect of the relative long term of 6 years $\mathrm{N}$ loading levels on the soil ammonia oxidizing prokaryotes in the semiarid temperate grassland soils.

\section{Conclusions}

In conclusion, $\mathrm{AOB}$ and $\mathrm{AOA}$ abundance and community structure under relative long-term $\mathrm{N}$ loading gradients in semiarid grassland were monitored by combining the quantitative PCR, T-RFLP, and sequencing methods. The archaeal amoA gene had a higher copy number than the bacterial amoA gene in N-limited grassland soil in natural conditions, with all AOB sequences affiliating to Nitrosospira- or Nitrosomonaslike species and all AOA sequences affiliating to soil and sediment lineage. Both abundance and composition of AOB were altered by the increasing $\mathrm{N}$ loading, but AOA showed nonsignificant changes in abundance and community composition. The relative long-term nitrogen loading of more than $2-4 \mathrm{~g} \mathrm{~N} \mathrm{~m}^{-2}$ year $^{-1}$ resulted in a diversity loss of AOB in this study, which is consistent with the previous findings in macroorganisms indicating that the soil ammonia oxidizing prokaryotes are sensitive in response to the $\mathrm{N}$ input in soil and can be used as a effective indicator for assessing ecosystem functions and soil sustainable management.

Acknowledgments This work was supported by the Natural Science Foundation of China (41020114001, 41025004 and 40871129) and the Chinese Academy of Sciences (KZCX2-YW-JC401). We are grateful to the Duolun Restoration Ecological Experimentation and Demonstration Station for access to the study sites and research facilities. 


\section{References}

Aber J, McDowell W, Nadelhoffer K, Magill A, Berntson G, Kamakea M, McNulty S, Currie W, Rustad L, Fernandez I (1998) Nitrogen saturation in temperate forest ecosystems - hypotheses revisited. Bioscience 48:921-934

Avrahami S, Conrad R (2003) Patterns of community change among ammonia oxidizers in meadow soils upon long-term incubation at different temperatures. Appl Environ Microbiol 69:6152-6164

Avrahami S, Conrad R, Braker G (2002) Effect of ammonium concentration on $\mathrm{N}_{2} \mathrm{O}$ release and on the community structure of ammonia oxidizers and denitrifiers. Appl Environ Microbiol 68:5685-5692

Bai YF, Han XG, Wu JG, Chen ZZ, Li LH (2004) Ecosystem stability and compensatory effects in the Inner Mongolia grassland. Nature 431:181-184

Bai YF, Wu JG, Clark CM, Naeem S, Pan QM, Huang JH, Zhang LX, Han XG (2010) Tradeoffs and thresholds in the effects of nitrogen addition on biodiversity and ecosystem functioning: evidence from inner Mongolia Grasslands. Glob Chang Biol $16: 358-372$

Di HJ, Cameron KC, Shen JP, Winefield CS, O'Callaghan M, Bowatte S, He JZ (2009) Nitrification driven by bacteria and not archaea in nitrogen-rich grassland soils. Nat Geosci 2:621-624

Di HJ, Cameron KC, Shen JP, Winefield CS, O'Callaghan M, Bowatte S, He JZ (2010) Ammonia oxidizing bacteria and archaea grow under contrasting soil nitrogen conditions. FEMS Microbiol Ecol 72:386-394

Francis CA, Roberts KJ, Beman JM, Santoro AE, Oakley BB (2005) Ubiquity and diversity of ammonia-oxidizing archaea in water columns and sediments of the ocean. P Natl Acad Sci USA 102:14683-14688

Geets J, Boon N, Verstraete W (2006) Strategies of aerobic ammoniaoxidizing bacteria for coping with nutrient and oxygen fluctuations. FEMS Microbiol Ecol 58:1-13

Hatzenpichler R, Lebedeva EV, Spieck E, Stoecker K, Richter A, Daims H, Wagner M (2008) A moderately thermophilic ammonia-oxidizing crenarchaeote from a hot spring. P Natl Acad Sci USA 105:2134-2139

He JZ, Shen JP, Zhang LM, Zhu YG, Zheng YM, Xu MG, Di HJ (2007) Quantitative analyses of the abundance and composition of ammonia-oxidizing bacteria and ammonia-oxidizing archaea of a Chinese upland red soil under long-term fertilization practices. Environ Microbiol 9:2364-2374

Horz HP, Barbrook A, Field CB, Bohannan BJM (2004) Ammoniaoxidizing bacteria respond to multifactorial global change. P Natl Acad Sci USA 101:15136-15141

Ibekwe AM, Grieve CM, Lyon SR (2003) Characterization of microbial communities and composition in constructed dairy wetland wastewater effluent. Appl Environ Microbiol 69:5060-5069

Könneke M, Bernhard AE, de la Torre JR, Walker CB, Waterbury JB, Stahl DA (2005) Isolation of an autotrophic ammonia-oxidizing marine archaeon. Nature 437:543-546

Kowalchuk GA, Stephen JR (2001) Ammonia-oxidizing bacteria: a model for molecular microbial ecology. Annu Rev Microbiol $55: 485-529$

Leininger S, Urich T, Schloter M, Schwark L, Qi J, Nicol GW, Prosser JI, Schuster SC, Schleper C (2006) Archaea predominate among ammonia-oxidizing prokaryotes in soils. Nature 442:806-809

Martens-Habbena W, Berube PM, Urakawa H, de la Torre JR, Stahl DA (2009) Ammonia oxidation kinetics determine niche separation of nitrifying archaea and bacteria. Nature 461:976-U234
McAndrew DW, Malhi SS (1992) Long-term N fertilization of a solonetzic soil-effects on chemical and biological properties. Soil Biol Biochem 24:619-623

Mendum TA, Sockett RE, Hirsch PR (1999) Use of molecular and isotopic techniques to monitor the response of autotrophic ammonia-oxidizing populations of the beta subdivision of the class Proteobacteria in arable soils to nitrogen fertilizer. Appl Environ Microbiol 65:4155-4162

Nicol GW, Schleper C (2006) Ammonia-oxidising Crenarchaeota: important players in the nitrogen cycle? Trends Microbiol $14: 207-212$

Nicol GW, Leininger S, Schleper C, Prosser JI (2008) The influence of soil $\mathrm{pH}$ on the diversity, abundance and transcriptional activity of ammonia oxidizing archaea and bacteria. Environ Microbiol 10:2966-2978

Niu SL, Wan SQ (2008) Warming changes plant competitive hierarchy in a temperate steppe in northern China. J Plant Ecol 1:103-110

Prosser JI, Nicol GW (2008) Relative contributions of archaea and bacteria to aerobic ammonia oxidation in the environment. Environ Microbiol 10:2931-2941

Rotthauwe JH, Witzel KP, Liesack W (1997) The ammonia monooxygenase structural gene amoA as a functional marker: molecular fine-scale analysis of natural ammonia-oxidizing populations. Appl Environ Microbiol 63:4704-4712

Schleper C (2010) Ammonia oxidation: different niches for bacteria and archaea. JSME J 4:1092-1094

Shen JP, Zhang LM, Zhu YG, Zhang JB, He JZ (2008) Abundance and composition of ammonia-oxidizing bacteria and ammoniaoxidizing archaea communities of an alkaline sandy loam. Environ Microbiol 10:1601-1611

Stephen JR, McCaig AE, Smith Z, Prosser JI, Embley TM (1996) Molecular diversity of soil and marine 16S rRNA gene sequences related to beta-subgroup ammonia-oxidizing bacteria. Appl Environ Microbiol 62:4147-4154

Tamura K, Dudley J, Nei M, Kumar S (2007) MEGA4: molecular evolutionary genetics analysis (MEGA) software version 4.0. Mol Biol Evol 24:1596-1599

Tilman D, Wedin D, Knops JMH (1996) Productivity and sustainability influenced by biodiversity in grassland ecosystems. Nature 379:718-720

Tilman D, Reich PB, Knops JMH (2006) Biodiversity and ecosystem stability in a decade-long grassland experiment. Nature 441:629632

Treusch AH, Leininger S, Kletzin A, Schuster SC, Klenk HP, Schleper C (2005) Novel genes for nitrite reductase and Amo-related proteins indicate a role of uncultivated mesophilic crenarchaeota in nitrogen cycling. Environ Microbiol 7:1985-1995

Ying JY, Zhang LM, He JZ (2010) Putative ammonia-oxidizing bacteria and archaea in an acidic red soil with different land utilization patterns. Environ Microbiol Rep 2:304-312

Yu ZY, Zeng DH, Jiang FQ, Zhao Q (2009) Responses of biomass to the addition of water, nitrogen and phosphorus in Keerqin sandy grassland, Inner Mongolia, China. J For Res 20:23-26

Zhang Y, Zheng LX, Liu XJ, Jickells T, Cape JN, Goulding K, Fangmeier A, Zhang FS (2008) Evidence for organic N deposition and its anthropogenic sources in China. Atmos Environ 42:1035-1041

Zhang LM, Wang M, Prosser JI, Zheng YM, He JZ (2009) Altitude ammonia-oxidizing bacteria and archaea in soils of Mount Everest. FEMS Microbiol Ecol 70:208-217

Zhang LM, Offre PR, He JZ, Verhamme DT, Nicol GW, Prosser JI (2010) Autotrophic ammonia oxidation by soil thaumarchaea. P Natl Acad Sci USA 107:17240-17245 